\title{
Clinico-epidemiological profile of HIV patients attending ART centre in rural Western Maharashtra, India
}

\author{
Jayant D. Deshpande ${ }^{1}$, Purushottam A. Giri ${ }^{2}$, Deepak B Phalke
}

${ }^{1}$ Associate Professor; ${ }^{2}$ Associate Professor; ${ }^{3}$ Professor and Head Department; Department of Community Medicine (PSM), Pravara Institute of Medical Sciences, Rural Medical College, Loni, Maharashtra, India.

\section{Abstract}

HIV infection represents a major public health problem for both developing and developed countries as it has grown to pandemic proportions worldwide. Spectrum of clinical presentation of HIV can vary with geographical distribution, socioeconomic and cultural environment. The aim of this study was to examine the socio-demographic characteristics, clinical presentations of HIV/AIDS patients, opportunistic infections and the possible risk factors for acquiring HIV infection. A cross sectional study was conducted from March to September, 2011 at an antiretroviral therapy (ART) centre of a rural tertiary care hospital, situated in Maharashtra state of India. History and physical examination was done and recorded on a pre-designed schedule which included the socio-demographic and clinical profile of the patients. More than half of the subjects were in economically productive age group and male patients $166(53.4 \%)$ outnumbered the female patients 145 (46.6\%). There was a predominance of patients from rural locations nearby the present ART centre. The patients were having low level of literacy and were from the lower middle and lower socio-economic classes. Among the spouses of male patients, $65(44.8 \%)$ were HIV positive and among the spouses of female patients, $52(35.7 \%)$ were HIV positive. Commonest mode of acquiring the infection was through heterosexual contact. Tuberculosis $(62 \%)$ was the most common opportunistic infection. As per the WHO staging, $132(42.5 \%)$ patients were in stage 3. Combination of behavioral risk factors and unawareness is responsible for rapid spread of HIV/AIDS. People with high-risk behavior and spouses of affected patients need to be educated for primary and secondary prevention.

Keywords: AIDS, ART, Clinico-epidemiological profile, HIV, India.

\section{Introduction}

The human immunodeficiency virus (HIV) infection is a global pandemic. Acquired immunodeficiency syndrome (AIDS) continues to be a major global health priority. According to the UNAIDS and World Health Organization (WHO) Report 2010, there are approximately 33.3 million people living with HIV/AIDS worldwide, with a global prevalence of $0.8 \% .{ }^{1}$ The HIV cases in South and South-east Asia account for 4.1 million people with HIV. ${ }^{1}$ It is estimated that $90 \%$ of the HIV infected persons live in the developing countries, with the estimated number of infected Indians being 2.31 million, with an adult prevalence of $0.3 \%$. ${ }^{1}$ Among the Indian states, Manipur has shown the highest estimate of the adult HIV prevalence of $1.4 \%$, followed by Andhra Pradesh (0.9\%), Mizoram $(0.8 \%)$, Nagaland $(0.78 \%)$, Karnataka $(0.63 \%)$ and Maharashtra $(0.55 \%) .^{2}$ India launched its free national antiretroviral therapy (ART) programme in April 2004 with financial support from the Global Fund to Fight AIDS, Tuberculosis and Malaria. ${ }^{3}$ ART has changed the face of HIV/AIDS by leading to a dramatic decrease in HIVrelated morbidity and mortality among those with access to therapy. ${ }^{4}$ ART is provided free by the government and increasing numbers of $\mathrm{HIV}$-infected persons are now

\section{Practice Points}

- Most of the affected population was from reproductive age group and heterosexual route was the commonest route of transmission of HIV infection.

- Married women were found to be more vulnerable to acquire HIV infection from their husbands.

- Fever, weight loss, cough, and diarrhea were the most frequent presenting symptoms and tuberculosis was the most common opportunistic infection.

- Combination of behavioral risk factors and unawareness is responsible for rapid spread of HIV/AIDS.

- People with high-risk behavior and the spouses of affected patients need to be educated for primary and secondary prevention.

Correspondence: Dr. Jayant D. Deshpande, Associate Professor, Department of Community Medicine (PSM), Department of Community Medicine (PSM), Pravara Institute of Medical Sciences, Rural Medical College, Loni, Tq. Rahata Dist, Ahmadnagar, Maharashtra, India. E-mail: drjayant10@gmail.com.

South East Asia Journal of Public Health 2012;2(2):16-21. (C) 2012 Deshpande et al., publisher and licensee Public Health Foundation Bangladesh. This is an Open Access article which permits unrestricted non-commercial use, provided the original work is properly cited. 
being treated with ART in India. There is a need to study the profile of patients who come to ART centers and link their clinical and socio-demographic variables in the management of treatment. Moreover, it is important to understand the presentation of HIV disease in the local context and culture. The present study is aimed at identifying the socio-demographic characteristics, clinical presentations of HIV/AIDS patients, opportunistic infections and the possible risk factors for acquiring HIV infection at an ART centre of a rural tertiary care hospital, situated in Maharashtra state of India.

\section{Materials and methods}

A cross-sectional study was conducted at ART centre of a rural tertiary care hospital, situated in Maharashtra state of India, from March to September, 2011. This study duration was randomly selected to avoid any selection bias. The study area is in a western part of Maharashtra state. Predominantly the study population was from the rural area around Loni along with some nearby urban area like Kopargaon, Shrirampur,Sangamner, Rahuri, etc. The HIV positive patients coming to ART centre for treatment were included in the study. Their demographic details, personal history, behavioral pattern were studied. Patients with HIV infection tend to present in advanced stages of acquired immunodeficiency syndrome (AIDS) and are usually referred to the hospital's ART centre. The centre receives financial and logistic support from National AIDS Control Organization (NACO). Patients were offered antiretroviral therapy if their CD4 lymphocyte count was less than $<350$ cells/ microlitre $(\mu \mathrm{l})$. If the patient is found clinically eligible, then one of the following first-line regimens is started: (i) Zidovudine (ZDV) (300 mg) +lamivudine (3TC) (150 mg)+nevirapine (NVP) (200 mg) or efavirenz (EFV) (600 mg), (ii) Stavudine (d4T) (30 mg) +3TC $(150 \mathrm{mg})+\mathrm{NVP}(200 \mathrm{mg})$ or EFV $(600 \mathrm{mg})$. Trimethoprim-Sulphamethoxazole prophylaxis was given to prevent Pneumocystis Carinii pneumonia in all patients with a CD4 lymphocyte count of $<200$ cells $/ \mu 1$.

\section{Data collection}

In the present study out of 311 patients, the male patients $166(53.4 \%)$ outnumbered the female patients 145 (46.6\%). Male to female ratio was 1.14:1. After explaining the objectives of the study and assuring the confidentiality of the subjects, permission was obtained from the Incharge Medical Officer of the ART centre. A questionnaire was used to collect the information from the HIV positive patients on ART attending the Out Patient services at the ART centre. Prior to commencement of the study a one-week pilot study was undertaken to look for flaws in the questionnaire. Informed consent was obtained. History and physical examination was done and recorded on a pre-designed schedule which included the socio-demographic and clinical profile of the patients. All enrolled HIV positive patients were seen by the treating physician and the relevant data was collected, which included information of age, sex, socioeconomic status (SES), background, education level, occupation, religion, marital status, sexual history, clinical features, opportunistic infections, laboratory parameters (CD4 counts). Socio-economic status was assessed by the modified BG Prasad classification based on the consumer price index. ${ }^{5}$ The clinical staging was done according to the World Health Organization (WHO) classification of HIV/AIDS. ${ }^{6}$ Clinical stage 1 includes asymptomatic patients. Clinical stage 2 includes minor weight loss, minor mucocutaneous manifestations, and recurrent upper respiratory tract infections. Clinical stage 3 includes weight loss $>10 \%$ of body weight, unexplained chronic diarrhea, unexplained persistent fever, oral candidiasis or leukoplakia, severe bacterial infections, pulmonary tuberculosis and acute necrotizing inflammation in the mouth. Clinical stage 4 includes 22 opportunistic infections or cancers related to HIV. All people with stage 4 have AIDS. ${ }^{6}$ Data was processed and analyzed with SPSS version 17.0. The demographic and opportunistic infections data were expressed in percentages. Chi square $\left(\chi^{2}\right)$ test was used as test of significance. A $p$-value $\leq 0.05$ was considered statistically significant.

\section{Result}

The distribution of patients according to the age showed that, the maximum number of males $128(77.1 \%)$ as well as females $122(84.1 \%)$ were in the age group of 15 -45 years. Maximum patients i.e. 176 (56.6\%) were residing in rural area while $135(43.4 \%)$ in urban area. There was a predominance of patients from rural locations nearby the present ART centre as $33(10.6 \%)$ patients lived less than $10 \mathrm{~km}$ from centre, 190 (61.1\%) 11 $-30 \mathrm{~km}$ and $50(16.1 \%) 31-50 \mathrm{~km}$. In the present study, out of 311 patients, $81(26.1 \%)$ were illiterate while 230 (74\%) were literate. Maximum numbers of females were illiterate $(39.3 \%)$ as compared to males $(14.5 \%)$. Among the patients studied 222 (71.4\%) were married. Almost one third of the females i.e. $49(33.8 \%)$ were widow. The patients were from the lower middle and lower socio-economic classes (Table 1). Most of them were working as laborers/farmer (55\%), housewife $(14.2 \%)$ and drivers $(4.8 \%)$. Laborers include the agricultural as well as nonagricultural laborers. There was no statistical difference in the socio-demographic parameters like age $\left(\chi^{2}=3.83\right.$; Degrees of freedom (d.f.) $=2, \quad p=0.14)$; Socioeconomic status $\left(\chi^{2}=6.6 ; \quad\right.$ d.f. $=4$, $p=0.15)$; and place of residence $\left(\chi^{2}=0.19\right.$; d.f. $=1$ $p=0.65$ ) amongst the male and the female patients There was statistical significant difference in the sociodemographic parameters like educational status $\left(\chi^{2}=33.52 ;\right.$ d.f $\left.=3, \quad p=0.000\right)$ and marital status $\left(\chi^{2}=61\right.$; d.f. $=1, p=0.000)$.

The most common presenting complaints were weight loss, fever, cough, and chronic diarrhea (Table 2). HIV status of $145(46.6 \%)$ spouses was known. Among the spouses of male patients $65(44.8 \%)$ were HIV positive and among the spouses of female patients $52(35.9 \%)$ were HIV positive. As expected majority of the patients belonged to the sexually active age group of 20 to 40 years, commonest mode of acquiring the infection was through heterosexual contact and $19(6.1 \%)$ patients acquired infection via vertical (mother to child) transmission. None of the patients gave a history of drug 
Table 1: Socio-demographic profile of HIV positive patients

\begin{tabular}{|c|c|c|c|}
\hline & $\begin{array}{c}\text { Male } \\
n-166(53.38 \%)\end{array}$ & $\begin{array}{c}\text { Female (\%) } \\
\text { n-145 (46.62\%) }\end{array}$ & $\begin{array}{l}\text { Total } \\
\mathrm{n}-311\end{array}$ \\
\hline \multicolumn{4}{|l|}{ Age(years) } \\
\hline$<15$ & $12(7.22 \%)$ & $4(2.75 \%)$ & $16(5.14 \%)$ \\
\hline $15-45$ & $128(77.1 \%)$ & $122(84.13)$ & $250(80.38)$ \\
\hline$>45$ & $26(15.66 \%)$ & $19(13.1)$ & $45(14.46)$ \\
\hline \multicolumn{4}{|l|}{ Education } \\
\hline Illiterate & $24(14.45 \%)$ & $57(39.31 \%)$ & $81(26.05 \%)$ \\
\hline Primary & $39(23.51 \%)$ & $25(17.24 \%)$ & $64(20.58 \%)$ \\
\hline Secondary & $83(50 \%)$ & $61(42.06 \%)$ & $144(46.30 \%)$ \\
\hline $\begin{array}{l}\text { Higher secondary and } \\
\text { above }\end{array}$ & $20(12.04 \%)$ & $2(1.37 \%)$ & $22(7.07 \%)$ \\
\hline \multicolumn{4}{|l|}{ Socioeconomic status } \\
\hline $\mathrm{I}$ & $16(9.63 \%)$ & $4(2.75 \%)$ & $20(6.43 \%)$ \\
\hline II & $64(38.55 \%)$ & $57(39.31 \%)$ & $121(38.92 \%)$ \\
\hline III & $72(43.37 \%)$ & $73(50.34 \%)$ & $145(46.62 \%)$ \\
\hline IV & $8(4.81 \%)$ & $6(4.13 \%)$ & $14(4.50 \%)$ \\
\hline $\mathrm{V}$ & $6(3.61 \%)$ & $5(3.44 \%)$ & $11(3.53 \%)$ \\
\hline \multicolumn{4}{|l|}{ Marital status } \\
\hline Unmarried & $29(17.46 \%)$ & $8(5.51 \%)$ & $37(11.89 \%)$ \\
\hline Married & $134(80.72 \%)$ & $88(60.68 \%)$ & $222(71.38 \%)$ \\
\hline Widow/widower & $3(1.8 \%)$ & $49(33.79 \%)$ & $52(16.72 \%)$ \\
\hline \multicolumn{4}{|l|}{ Residence } \\
\hline Rural & $92(55.42 \%)$ & $84(57.93 \%)$ & $176(56.59 \%)$ \\
\hline Urban & $74(44.58 \%)$ & $61(42.07 \%)$ & $135(43.41 \%)$ \\
\hline
\end{tabular}

abuse or homosexual behavior in present study. Out of the 311 patients, $147(47.3 \%)$ were on ZDV+3TC+NVP combination and $98(31.5 \%)$ were on $\mathrm{d} 4 \mathrm{~T}+\mathrm{TC}+\mathrm{NVP}$ (Table 3).

Tuberculosis $(62 \%)$ was the most common opportunistic infection. Other presentations like pneumosystis carinii pneumonia, herpes zoster, malignancy, candidiasis, neurological disorders and ophthalmic manifestations were noted. As the number of CD4 count decreased, incidence and the number of opportunistic infections per patient increased. As per the WHO staging ${ }^{4}, 132$ $(42.5 \%)$ patients were in stage 3 (Table 4 ).

\section{Discussion}

The epidemic of HIV/AIDS in India is shifting from the highest risk group (commercial sex workers, drug users) to bridge population (clients of sex workers, STD patients and partners of drug users) and then to general population. In present study, more than half of the subjects were in economically productive age group and majority of patients who sought ART were males. In a study done by Mandal et al., ${ }^{7} 81.16 \%$ of cases were in the age group of 20-40 years with male to female ratio of $1.5: 1 \mathrm{HIV}$ seems to be affecting the economically productive, sexually active group and thus having a tremendous impact on the livelihood of the affected family. The distribution according to educational status showed that the seropositivity was higher among the subjects with lesser education. These findings are similar to the study conducted by Jayaram et al. ${ }^{8}$ in Karnataka, India. Low education status and less awareness regarding safe sex can be the reason for high prevalence among this group of people. Most of the patients in present study were from the lower-middle and lower socio-

Table 2: Presenting complaints of patients attending ART centre*

\begin{tabular}{|l|c|c|c|}
\hline Complaints & $\begin{array}{c}\text { Male } \\
\mathrm{n}-166(\%)\end{array}$ & $\begin{array}{c}\text { Female } \\
\mathrm{n}-145(\%)\end{array}$ & $\begin{array}{c}\text { Total } \\
\mathrm{n}-311(\%)\end{array}$ \\
\hline Weight loss & $128(77.10 \%)$ & $98(67.58 \%)$ & $226(72.66 \%)$ \\
\hline Chronic fever & $75(45.18 \%)$ & $88(60.68 \%)$ & $163(52.41 \%)$ \\
\hline Cough & $58(34.93 \%)$ & $48(33.10 \%)$ & $106(34.08 \%)$ \\
\hline Body pain & $34(20.48 \%)$ & $68(46.89 \%)$ & $102(32.15 \%)$ \\
\hline Fatigue & $42(25.30 \%)$ & $58(40.00 \%)$ & $100(32.79 \%)$ \\
\hline Chronic diarrhea & $54(32.53 \%)$ & $44(30.34 \%)$ & $98(31.51 \%)$ \\
\hline Malaise & $38(22.89 \%)$ & $42(28.96 \%)$ & $80(25.72 \%)$ \\
\hline Breathlessness & $25(15.06 \%)$ & $07(4.82 \%)$ & $32(10.28 \%)$ \\
\hline Lymphadenopathy & $18(10.84 \%)$ & $12(8.27 \%)$ & $30(9.64 \%)$ \\
\hline Generalized pruritic dermatitis & $2(1.20 \%)$ & $1(0.68 \%)$ & $3(0.96 \%)$ \\
\hline
\end{tabular}

*Multiple responses

South East Asia Journal of Public Health 2012;2(2):16-21. 
Table 3: Clinical profile of patients attending ART centre

\begin{tabular}{|c|c|}
\hline Clinical profile & Number $(\%)$ \\
\hline \multicolumn{2}{|l|}{ Family history } \\
\hline Husband positive & $52(35.86 \%)$ \\
\hline Wife positive & $65(44.82 \%)$ \\
\hline Parents positive & $18(12.42 \%)$ \\
\hline Child/children positive & $10(6.89 \%)$ \\
\hline Total & 145 \\
\hline \multicolumn{2}{|c|}{ Routes of transmission of HIV infection } \\
\hline Heterosexual & $287(92.28 \%)$ \\
\hline Mother to child & $19(6.11 \%)$ \\
\hline Blood transfusion & $5(1.61 \%)$ \\
\hline Intravenous drug abuse & 0 \\
\hline Homosexual & 0 \\
\hline \multicolumn{2}{|l|}{ ART Regimes } \\
\hline $\begin{array}{l}\text { Zidovudine }+ \text { Lamivudine }+ \\
\text { Nevirapine }\end{array}$ & $147(47.26 \%)$ \\
\hline $\begin{array}{l}\text { Stavudine + Lamivudine + } \\
\text { Nevirapine }\end{array}$ & $98(31.51 \%)$ \\
\hline $\begin{array}{l}\text { Stavudine + Lamivudine + } \\
\text { Efavirenz }\end{array}$ & $34(10.95 \%)$ \\
\hline $\begin{array}{l}\text { Zidovudindine + Lamivudine + } \\
\text { Efavirenz }\end{array}$ & $32(10.28 \%)$ \\
\hline
\end{tabular}

economic classes and were working as laborers/farmer, housewives and drivers. Mandal et al. ${ }^{7}$ found that the main risk groups were truck drivers and laborers. Most of the females i.e. $49(33.8 \%)$ were widow. Most of the widows gave history of death of their husbands due to HIV/AIDS. The reason for more number of attendees those were housewife can be gaining of infection by unsafe sex from their HIV positive husband or any other sexual partner. This point-out the unsafe sexual practices among married couple. There was a predominance of patients from rural locations nearby the present ART centre. This type of distribution in the present study might be due to the rural location of ART centre, easier access by the rural people or it might indicate real increase in the HIV prevalence in the rural areas of the district.

The major manifestations of HIV/AIDS, reported in this study namely: weight loss, chronic fever and diarrhea are comparable with previous reports., ${ }^{9,10}$ Though numerous other studies have reported about some other complaints like problem in conception ${ }^{11}$, fertility ${ }^{12}$ and neurological disorders. ${ }^{13}$ In this study, heterosexual mode of transmission was the major mode of transmission in $92.3 \%$ of the cases. Sexual, especially the heterosexual, transmission is the main driver of the epidemic in most of India. Kothari et al. ${ }^{14}$ showed that heterosexuality accounted for $90 \%$ of the total cases. Tuberculosis $(62 \%)$ was the most common opportunistic infection in present study. In India, the most common opportunistic infection among people with HIV infection is pulmonary tuberculosis. ${ }^{15-17}$ The rates of HIV/TB co-infection have been reported to vary in different regions of India. In North India, it was found to be between 0.4 and $20.1 \%{ }^{18}$ Low level of immunity makes them susceptible to fresh TB infection or reactivation of latent infection. The risk of developing TB after an infectious contact is $5-10 \%$ per year among HIV infected individuals compared to $5-10 \%$ per cent during the lifetime of HIV-negative individuals. ${ }^{19}$

CD4 count is one of most reliable investigation for clinical staging of patients and used to make decision on treatment initiation along with opportunistic infections. The prolonged course of HIV infection is marked by a decrease in the number of circulating $\mathrm{CD} 4+\mathrm{T}$ helper cells and persistent viral replication, resulting in immunologic decline and death from opportunistic infections and neoplasms. ${ }^{20}$ Majority of patients presented with an initial CD4 count of less than 300cells/ $\mu$ l consistent to previous study. ${ }^{21}$ In present study ZDV+3TC+NVP and $\mathrm{d} 4 \mathrm{~T}+3 \mathrm{TC}+\mathrm{NVP}$ combination was prescribed to $47.3 \%$ and $31.5 \%$ patients respectively. In a study by Bachani et al. ${ }^{22} 71 \%$ of patients were started on $\mathrm{d} 4 \mathrm{~T}+3 \mathrm{TC}+\mathrm{NVP}$ and $\mathrm{ZDV}+3 \mathrm{TC}+\mathrm{NVP}$ was prescribed to $28 \%$ of the patients. Though, ART does not cure HIV/AIDS, but effective ART regimens inhibit the efficient replication of the HIV virus, and reduce viremia. HIV-infected patients with CD4 counts $<200$ cells $/ \mathrm{mm} 3$ are at higher risk of opportunistic diseases, non-AIDS morbidity, and death than HIV-infected patients with higher CD4 counts. Randomized controlled trials in patients with CD4 counts $<200$ cells/ $\mu 1$ and/or a history of an AIDSdefining condition provide strong evidence that ART improves survival and delays disease progression in these patients. ${ }^{23,24}$

The study has a number of limitations. This study was conducted at an ART centre of a rural tertiary care hospital in Maharashtra state of India, therefore, caution needs to be taken to generalize the findings. Moreover, as this is a cross-sectional study, associations have been established among variables but not the casual inferences. A gap still exists between those detected as HIVpositives and those who report on ART centre.

\section{Conclusion}

The study found that most of the affected population was from reproductive age group and male preponderance with heterosexual route being the commonest mode of transmission. Married women were found to be more vulnerable to acquire HIV infection from their husbands. Fever, weight loss, cough, and diarrhea were the most frequent presenting symptoms and tuberculosis was the most common opportunistic infection. Combination of behavioral risk factors and unawareness is responsible for rapid spread of HIV/AIDS. People with high-risk behavior and the spouses of affected patients need to be educated for primary and secondary prevention.

\section{Acknowledgement}

The authors gratefully acknowledge the support from the Management of Pravara Medical Trust, Principal Rural Medical College Loni, Dr. S. C. Tiwari, Professor and Head, Department of Medicine, and Dr P. P. Pargaonkar, Medical Officer, ART Clinic. We appreciate the help of Third M.B.B.S. students in the study. 
Table 4: Opportunistic infections, CD4 Cell count and WHO clinical staging

\begin{tabular}{|c|c|c|c|}
\hline & Male (\%) & Female (\%) & Total (\%) \\
\hline \multicolumn{4}{|c|}{ Opportunistic infections } \\
\hline Tuberculosis & $46(63.88 \%)$ & $21(58.33 \%)$ & $67(62.03 \%)$ \\
\hline Pneumonia & $7(9.72 \%)$ & $5(13.88 \%)$ & $12(11.11 \%)$ \\
\hline Malignancy & $5(6.94 \%)$ & $4(11.11 \%)$ & $9(8.33 \%)$ \\
\hline Herpes zoster & $6(8.33 \%)$ & $2(5.55 \%)$ & $8(7.45 \%)$ \\
\hline Eye disorder & $4(5.55 \%)$ & $3(8.33 \%)$ & $7(6.39 \%)$ \\
\hline Candidiasis & $2(2.77 \%)$ & $1(2.77 \%)$ & $3(2.77 \%)$ \\
\hline Neurological & $2(2.77 \%)$ & 0 & $2(1.86 \%)$ \\
\hline Total & $72(66.66 \%)$ & $36(33.34 \%)$ & $108(100 \%)$ \\
\hline \multicolumn{4}{|l|}{$H I V-T B$} \\
\hline Pulmonary & $35(21.08 \%)$ & $14(9.65 \%)$ & $49(15.75 \%)$ \\
\hline Extra pulmonary & $3(1.80 \%)$ & $2(1.37 \%)$ & $5(1.60 \%)$ \\
\hline Both & $8(4.81 \%)$ & $5(3.44 \%)$ & $13(4.18 \%)$ \\
\hline Not having TB & $120(72.28 \%)$ & $124(85.51 \%)$ & $244(78.45 \%)$ \\
\hline Total & $166(53.38 \%)$ & $145(46.62 \%)$ & $311(100 \%)$ \\
\hline \multicolumn{4}{|c|}{ CD4 Cell count (cells/ $\mu \mathrm{l})$} \\
\hline$\leq 50$ & $18(10.84 \%)$ & $12(8.27 \%)$ & $30(9.60 \%)$ \\
\hline $51-100$ & $25(15.06 \%)$ & $28(19.31 \%)$ & $53(17.04 \%)$ \\
\hline $101-150$ & $26(15.66 \%)$ & $20(13.79 \%)$ & $46(14.70 \%)$ \\
\hline $151-200$ & $34(20.49 \%)$ & $29(20 \%)$ & $63(20.65 \%)$ \\
\hline $201-250$ & $23(13.85 \%)$ & $27(18.62 \%)$ & $50(16.09 \%)$ \\
\hline $251-300$ & $8(4.81 \%)$ & $7(4.82 \%)$ & $15(4.60 \%)$ \\
\hline $301-350$ & $11(6.63 \%)$ & $8(5.51 \%)$ & $19(6.10 \%)$ \\
\hline Above 350 & $21(12.65 \%)$ & $14(9.65 \%)$ & $35(11.25 \%)$ \\
\hline Total & $166(53.38 \%)$ & $145(46.62 \%)$ & $311(100 \%)$ \\
\hline \multicolumn{4}{|c|}{ WHO clinical staging } \\
\hline Stage 1 & $29(17.47 \%)$ & $25(17.24 \%)$ & $54(17.36 \%)$ \\
\hline Stage 2 & $59(35.54 \%)$ & $54(37.24 \%)$ & $113(36.33 \%)$ \\
\hline Stage 3 & $71(42.77 \%)$ & $61(42.07 \%)$ & $132(42.45 \%)$ \\
\hline Stage 4 & $7(4.21 \%)$ & $5(3.45 \%)$ & $12(3.85 \%)$ \\
\hline Total & $166(53.38 \%)$ & $145(46.62 \%)$ & $311(100 \%)$ \\
\hline
\end{tabular}

\section{References}

1. UNAIDS. Global report: UNAIDS report on the global AIDS epidemic 2010. Geneva: Joint United Nations Programme on HIV/AIDS (UNAIDS), 2010.

2. National Aids Control Organization, Department of AIDS Control. HIV declining in India; New infections reduced by 50\% from 2000-2009; Sustained focus on prevention required. Press Release on 01 December 2010. http:// Www.nacoonline.org/upload/HomePage/ NACO $\% 20$ Press $\% 20$ Release $\% 20$ on $\% 20$ HIV $\%$ 20Estimates.pdf (accessed on July 2012)

3. National AIDS Control Organisation, Department of AIDS Control. Annual Report 2011-12. New Delhi: Ministry of Health \& Family Welfare, .

4. Palella FJ, Delaney KM, Moorman AC, Loveless MO, Fuhrer J, Satten GA, et al. Declining morbidity and mortality among patients with advanced HIV infection. $N$ Engl $J$ Med 1998;338:853-60.
5. Kumar P. Social classification - Need for constant updating. Indian J Community Med 1993; 18:60-61.

6. World Health Organization. Clinical staging of HIV/AIDS. http://www.who.int/hiv/pub/ guidelines/en/ (accessed on July 2012)

7. Mandal AK, Singh VP, Gulati AK. Prevalence of Human Immuno deficiency virus infection in and around Varanasi, Uttar Pradesh. Ind J Assoc Physicians 2000;48:288-9.

8. Jayaram S, Shenoy S, Unnikrishnan B, Ramapuram J, Rao M. Profile of attendees in Voluntary Counseling and Testing Centers of a Medical College Hospital in Coastal Karnataka. Ind $J$ Comm Med 2008; 33:43-6.

9. Boruah PK, Adhikari AK. Clinical spectrum of HIV/AIDS presenting to Gauhati Medical College. J Assoc Physicians Ind 2003;51:1258-60.

10. Tsega E. The demographic, social and clinical presentations of one hundred Ethiopian patients with HIV infection. Ethiop Med J 1990; 28:81-8. 
11. Setel P. The effects of HIV and AIDS on fertility in East and Central Africa. Heal Trans Rev 1995;5:179-89.

12. Sengupta P. Health impacts of yoga and Pranayama: A state-of-the-art review. Int J Prev Med 2012; 3:444-58.

13. Samson K. Longer HIV-AIDS survival raises likelihood of neurological problems. Neurol Today 2003; 3: 38-40.

14. Kothari K, Goyal S; Study of clinical presentation, spectrum of systemic involvement and opportunistic infections in AIDS patients. $J$ Assoc Physicians Ind 2001;49:435-438.

15. Narain JP, Pontali E, Tripathy S. Sentinel surveillance for HIV infection in tuberculosis patients in India. Ind $J$ Tuberc 2002;49:17-20.

16. Kumarasamy N, Solomon S, Flanigan TP, Hemalatha R, Thyagarajan SP, Mayer KH. Natural history of human immunodeficiency virus disease in southern India. Clin Inf Dis 2003; 36:79-85.

17. Nair SP, Moorty KP, Suprakasan S. Clinicoepidemiological study of HIV patients in Trivandrum. Ind $J$ Dermatol Venereol Leprol 2003;69:100-3.

18. Sharma SK, Agarwal G, Seth P, Saha PK. Increasing seropositivity among adult tuberculosis patients in Delhi. Ind J Med Res 2003;117:23942.
19. Ravilglione M, Harries A, Msika R, Wilkinson D, Nunn P. Tuberculosis and HIV current status in Africa. AIDS 1997;11:S115-23.

20. Pantaleo G, Fauci A. Immunopathogenesis of HIV infection. Annu Rev Microbiol 1996;50:82554.

21. Sharma SK, Kadhiravan $T$, Banga A, Goyal $T$, Bhatia I, Saha PK. Spectrum of clinical disease in a series of 135 hospitalized HIV-infected patients from north India. BMC Infect Dis 2004;4:52.

22. Bachani D, Garg R, Rewari B, Hegg L, Deshpande A. Two-year treatment outcomes of patients enrolled in India's national first-line antiretroviral therapy programme. Natl Med $J$ India 2010; 23:7-12.

23. HIV Trialists' Collaborative Group. Zidovudine, didanosine, and zalcitabine in the treatment of HIV infection: meta-analyses of the randomised evidence. Lancet 1999;353:2014-25.

24. Hammer SM, Squires KE, Hughes MD, Grimes JM, Demeter LM, Currier JS, et al. A controlled trial of two nucleoside analogues plus indinavir in persons with human immunodeficiency virus infection and CD4 cell counts of 200 per cubic millimeter or less. AIDS Clinical Trials Group 320 Study Team. N Engl J Med 1997;337:72533. 